\title{
Analysis on the Corrosion Performance of Friction Stir Welding Joint of 7022 Aluminum Alloy
}

\author{
Hong-feng Wang ${ }^{1,2}$, Jian-li Wang ${ }^{1}$, Wei-wei Song ${ }^{1}$, Dun-wen Zuo ${ }^{2}$, Ding-lin Shao ${ }^{2}$ \\ ${ }^{1}$ College of Mechanical and Electrical Engineering, Huangshan University, Huangshan 245041, \\ P.R.China; \\ ${ }^{2}$ College of Mechanical and Electrical Engineering, Nanjing University of Aeronautics and \\ Astronautics, Nanjing 210016, P.R.China) \\ *E-mail: jnjllhy@163.com
}

doi: $10.20964 / 2016.08 .09$

Received: 22 March 2016 / Accepted: 23 May 2016 / Published: 7 July 2016

The corrosion performances of base metal (i.e. 7022 aluminum alloy) and the welded joints under different process parameters of 7022 aluminum alloy in the mixed solution of $\mathrm{Na}_{2} \mathrm{SO}_{4}+$ dilute $\mathrm{H}_{2} \mathrm{SO}_{4}$ $(\mathrm{pH}=5)$ were studied by the weight-loss method and electrochemical method. The weight-loss method results showed that the base metal and the welded joints under different process parameters were occurred corrosion on their surfaces, and the base metal corrosion was far greater than the welded joints under different process parameters, the parameter for 400/30 welded joint corrosion was minimum. The electrochemical corrosion results were consistent with weight-loss method. Under various parameters of welded joints corrosion rate were not consistent, the parameters for $400 / 30$ welded joint corrosion rate was lowest. The electrochemical corrosion results showed that the base metal corrosion was mainly for pitting and denser distribution. The welded joints under different process parameters corrosion were appeared only a small amount of spot, their corrosion degree were small.

Keywords: friction stir welding; 7022 aluminum alloy; corrosion performance; electrochemical method; weight-loss method

\section{FULLTEXT}

(C) 2016 The Authors. Published by ESG (www.electrochemsci.org). This article is an open access article distributed under the terms and conditions of the Creative Commons Attribution license (http://creativecommons.org/licenses/by/4.0/). 